\title{
Instructional competence and practices of teachers in the new normal: Basis for training program
}

\author{
Nazareth, Riezel N. \\ Emilio Aguinaldo College, Manila, Philippines (razenicole@gmail.com)
}

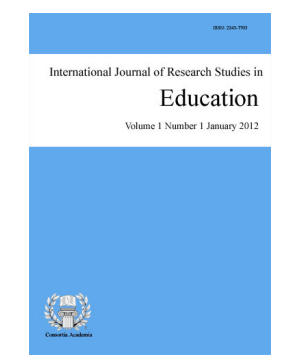

Accepted: 9 August 2021 Online ISSN: 2243-7711

OPEN ACCESS

\section{Abstract}

This study aimed to determine the instructional competence and practices of teachers in the new normal. Specifically, this was intended to determine the learning environment, content of learning, teaching and learning strategy, resources of learning, communication in teaching and learning, sustaining interest in learning and evidence of learning of teachers. Descriptive survey method was used and the target respondents were thirty selected teachers under district of Buenavista. Questionnaire was the main instrument used for the data collection. Percentage distribution, weighted mean, were used to analyze the data. Findings revealed that the respondents belong to age bracket 26 to 30; majority were female with Master's units and teaching English for not more than five years as teacher 1 in Elementary school. They already attended more than ten seminars. The study further revealed that teacher respondents were highly competent in terms of getting evidence of learning and teaching-learning strategy. However, communication in teaching and learning was found out to be lowest in rank that needs to develop. It is therefore recommended that teachers should use online platforms for communication in teaching and learning in order to reach the students and parents in the new normal setting. Furthermore, the Training Program is recommended to train teachers for the less competence identified.

Keywords: competence, instructional practices, content of learning, teaching-learning strategy, resource and communication, evidence of learning 


\section{Instructional competence and practices of teachers in the new normal: Basis for training program}

\section{Introduction}

Competence of teachers nowadays is very vital and play critical role in the student learning and achievement especially in this time of pandemic that the teachers have limited capacity to extend their competence, knowledge and skills. This brought challenges to teachers in terms of teaching performance and delivery of learning and instruction. This event brought many restrictive movement policies that may give constraint to teaching competence. Bas and Beyhan (2019) conducted a study to evaluate the effect of teaching of learning strategies on academic achievement of students. According to their study, there was no significant effect on teaching strategies of the academic achievement of students. While one the study of Tety (2016) pointed out that instructional materials are the key to teachers' and students' performance. The study of Khan et al. (2017) indicates that majority of the students opined that they learn well from those teachers who has good communication skills or who adopt good communication skills while dealing inside and out of the institution.

The researcher will determine the profile of the teacher respondents in terms of age, sex, educational attainment, position/designation, years in service, school level, major subjects being taught, seminars attended for the last five years related to the topic; instructional competence and practices such as learning environment, content learning, teaching-learning strategy, learning resources, communication in teaching and learning, sustaining interest in learning and evidence in learning.

\section{Research methodology}

This research will use the descriptive research method in order to achieve the purpose which is to determine and describe the instructional competence and practices of teachers in the new normal. This study will utilize the following instruments including Survey Questionnaire. The researcher will prepare a questionnaire based on the New Normal-Appropriate Instructional Practices used by Deped schools in the Division of Quezon (DM No. 368, s 2020).

Theory and calculation - This research was anchored on the Self-Determination Theory is a theory of human motivation and personality that concerns people's inherent growth tendencies and innate psychological needs. It has three variables such as competence, autonomy and relatedness Deci and Ryan (2014). These variables are interrelated to each other as we relate it to the study focus on the competence of the teachers and instructional practices. This shows that if the teacher is self-determined, he was able to do practices independently, so that is autonomy then competence comes next especially if he has the mastery and known the practices and that is relatedness.

Mathematical expressions and symbols - To show the demographic profile of the respondents, the researcher will use the percentage distribution and it will be presented in tables and graphs. Weighted mean will also be used to identify the instructional competence and practices of teachers for sub problem no 2.

\section{Results and discussion}

Based on the gathered, evaluated and interpreted data, the following findings were drawn: majority of the respondents belongs to $26-30$ years of age with $43.33 \%$; female got the highest frequency with $83.33 \%$; majority of the respondents has taken master's units which has 17 frequency and $56.67 \%$ and bachelor's degree has the second highest frequency which means the teachers were engaging in Master's degree and professional enhancement; teacher 1 has the highest frequency of 22 with $73.33 \%$ which means that many teachers are not yet 
promoted; 0-5 years in service got the highest frequency of 15 or $50 \%$ which means that most of the teachers-respondents are new to the service; school level, most of the respondents were from elementary school which has 17 frequency or 56.67\%; among the subjects, English has the highest frequency which got 9 frequency and next is T.L.E. which got 6 frequency or 20\%; and seminars attended for the last 5 years, majority of the respondents attended more than 10 seminars which got 21 frequency or $70 \%$. Figures and Tables

Table 1

Instructional competence and practices of teacher respondents

\begin{tabular}{lccc}
\hline \multicolumn{1}{c}{ Variables } & Mean & Interpretation & Rank \\
\hline A. Learning Environment & 3.40 & Competent & 5 \\
B. Content Of Learning & 3.37 & Competent & 6 \\
C. Teaching-Learning Strategy & 3.59 & Highly Competent & 2 \\
D. Resources of Learning & 3.44 & Competent & 4 \\
E. Communication in Teaching and Learning & 3.33 & Competent & 7 \\
F. Sustaining Interest in Learning & 3.49 & Competent & 3 \\
E. Getting Evidence of Learning & 3.60 & Highly Competent & 1 \\
\multicolumn{1}{c}{ General Weighted Mean } & 3.46 & Competent & \\
\hline
\end{tabular}

Legend: 3.51-4.00 Highly competent; 2.51-3.50 Competent; 1.51-2.50 Fairly competent; 1.00-1.50 Not competent.

For the instructional competence and practices of teachers, the general weighted mean is 3.46 which interpreted as Competent. This revealed that the instructional competence and practices of teachers were evidently competent. The highest mean among the instructional practices is 3.60 which is the Evidence of Learning which interpreted as Highly Competent. The next in rank which interpreted as Highly Competent also is the Teaching-Learning Strategy which has 3.59 weighted mean. Next to rank are Sustaining Interest in Learning, Resources of Learning, Learning Environment, Content of Learning and the last in rank is the Communication in Teaching and Learning which got 3.33 weighted mean. This was revealed also on the study of Basco (2017), according to her, teachers' strengths must work and complement the learning needs and requirements of the entire student population. The competencies required by the standard focus on the conditions which affect student learning. These will lead teachers to develop expertise needed to enable the students to function as independent thinkers and creative learners both within the school-community and in the larger society as well.

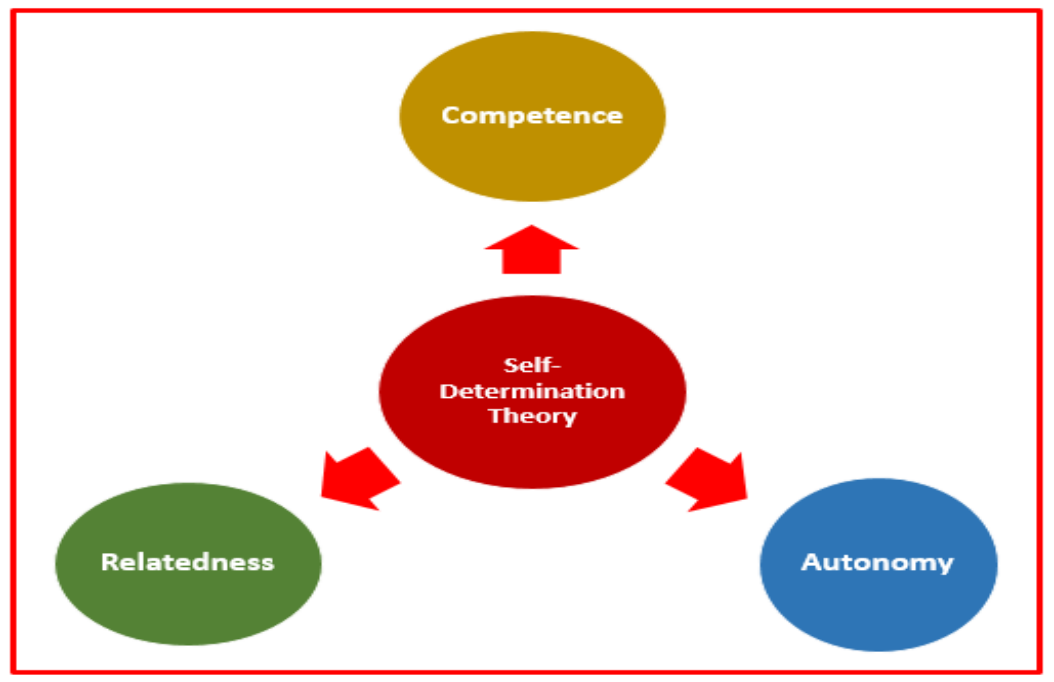

Figure 1. Self-Determination Theory 


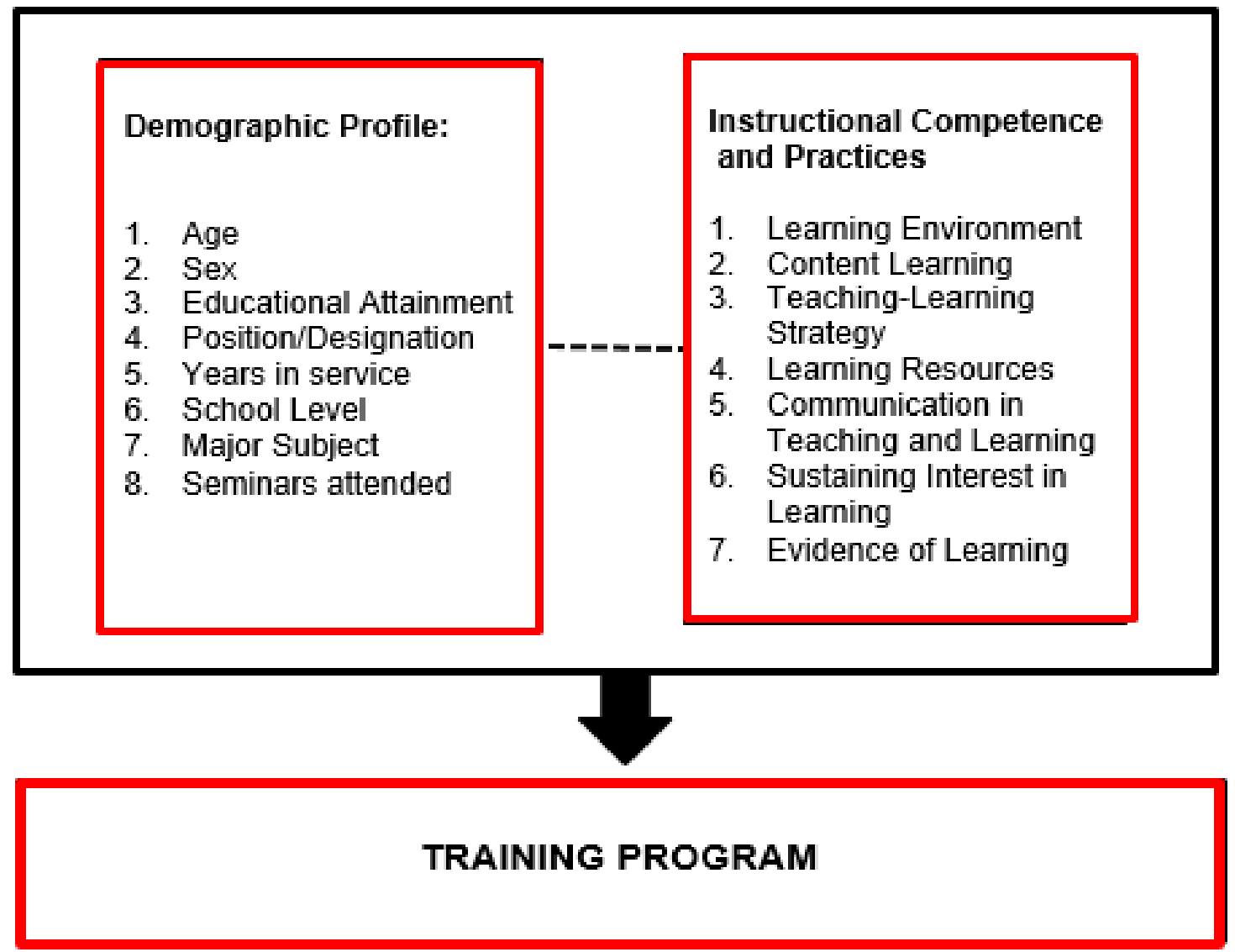

Figure 2. Research Paradigm

\section{Conclusions}

The researcher concluded that age, sex educational attainment, position or designation, years in service and school level indicated as significant in identifying respondent's demographic profile in order to determine the competence and instructional practices of teachers. Female teachers who are at early age with Master's units, Teacher 1 in position, new to the teaching service from elementary level, English was the common major subject and more than 10 seminars were being attended for the last five years are the indicating profile and factors that affect the competence and instructional practices of teachers.

The researcher concluded that teachers are highly competent in terms of getting evidence of learning which means that teachers' resourcefulness and creativity are implied in the learners' output. A systematic collection of the evidence of learning without sacrificing the safety and health of the school stakeholders is in place by the teacher respondents. Also, teachers provide data on learners' measurement of the attainment of the MELCs. They are also highly competent in terms of Teaching-Learning Strategy which means that the strategy employed by the teachers is purposeful and well-planned. The teacher utilized that is new normal appropriate. The learner is also instructed properly on how to accomplish efficiently the learning activities without hassle. The strategy used by the teacher is adequate to attain the desired learning outcomes. The teachers need to enhance their competence in terms of Communication in Teaching and Learning. Teachers need to improve the communication in teaching and learning to learners and parents. They should also utilize group chats to keep every school personnel and other stakeholders updated on the undertakings of the school. 


\section{References}

Altmann, U. (2015). Learning environment: The influence of school and classroom space on education. In C. Rubie-Davies, J. M. Stephens, \& P. Watson (Eds.), Routledge international handbook of social psychology of the classroom (pp. 252-262). Routledge.

Bas, G., \& Beyhan, O. (2019). Revisiting the effect of teaching of learning strategies on academic achievement: A meta-analysis of the findings. International Journal of Research in Education and Science, 5(1), $70-87$.

Basco, M. (2017). Assessment of the instructional competence of college science teachers in a selected university. International Journal of Humanities Social Sciences and Education, 4(10), 59-62. https://doi.org/10.20431/2349-0381.0410008

Chue, K., \& Nie, Y. (2016). International students' motivation and learning approach: A comparison with local students. Journal of International Students, 6(3), 678-699. https://doi.org/10.32674/jis.v6i3.349

Deci, E., \& Ryan, R. (2014). Self-determination theory in learning theories. Retrieved from https://www.learning-theories.com/self-determination-theory-deci-and ryan.html https://doi.org/10.1016/B978-0-08-097086-8.26036-4

Lucero, J. (2018). Instructional competence of teachers: Basis for learning action cell sessions. International Journal of Novel Research in Education and Learning, 5(4), 5-8.

Ozerem, A., \& Akkoyunlu, B. (2015). Learning environments designed according to learning styles and its effects on mathematics achievement. Eurasian Journal of Educational Research, 61, 61-80. https://doi.org/10.14689/ejer.2015.61.4

Pokhrel, S., \& Chhetri, R. (2021). A literature review on impact of COVID-19 pandemic on teaching and learning. Higher Education for the Future, 8(1), 133-141. https://doi.org/10.1177/2347631120983481

Shamaki, T. (2015). Influence of learning environment on students' academic achievement in mathematics: A case study of some selected secondary schools in Yobe State - Nigeria. Journal of Education and Practice, 6(34).

Tariq, N., \& Rashid, H. (2018). The impact of communication between teachers and students: A case study of the faculty of management sciences, University of Karachi, Pakistan. European Scientific Journal, 14(16). https://doi.org/10.19044/esj.2018.v14n16p32 
Nazareth, R. N.

66 Consortia Academia Publishing (A partner of Network of Professional Researchers and Educators) 